\title{
Oxidation of carbohydrates and fat in newly hatched chickens
}

\author{
A. Chwalibog ${ }^{1,3}$, A.-H. Tauson', C. Matthiesen', A. Ali', \\ K. Thorhauge ${ }^{1}$, E. Sawosz ${ }^{2}$ and G. Thorbek \\ 'Department of Animal and Veterinary Basic Sciences, \\ The Roval Veterinary and Agricultural University \\ Bülowsvej 13, 1870 Frederiksberg C, Denmark \\ 'Department of Animal Nutrition and Feed Science, Agricultural University of Warsaw \\ Ciszewskiego 8, 02-786 Warsaw, Poland
}

\begin{abstract}
Twenty-four newly hatched chickens from fast growing line (A) and slow growing line (B) of White Plymouth Rock were measured during the growth period from 1 to 13 days of age. Individua! 3-h measurements of $\mathrm{O}_{2}$ consumption and $\mathrm{CO}_{2}$ production were carried out in an open-air-circuit respiration unit. The gas exchange data were used to calculate oxidation of carbohydrates $(\mathrm{OXCHO})$ and fat (OXF). (hickens from line $A$ showed better growth performance and higher heat production. The contribution of OXCIIO and OXF to heat production showed remarkable differences between lines. From the $4^{\text {th }}$ day of age, about $90 \%$ of the heat was covered by OXCHO in line $\mathrm{A}$. while it decreased steadily from 77 to $29 \%$ in line B. The results indicate that in line A, breeding, causing greater feed intake and higher body gains, at the same time has changed the patterns of OXCHO and OXF compared with the slow growing line $\mathrm{B}$.
\end{abstract}

KEY WORDS: carbohydrate, fat, heat production, oxidation, chicken

\section{INTRODUCTION}

During the last several decades there has been intensive selection for growth rate in broilers. Modem lines of chickens eat more and consequently grow faster than unimproved birds. They have better feed utilization, hence their energy utilization is improved (Sørensen et al., 1983; MacLeod and Geraert, 1988). However, the question remains about how energy utilization is improved. Assuming that stoichiometric efficiencies of biochemical pathways of nutrient metabolism remain constant, one of the reasons may be a different partition between energy fuels. In earlier experiments

\footnotetext{
${ }^{3}$ Corresponding author: e-mail: ac $(a)$ kvl.dk
} 
with laying hens (Chwalibog, 2002) it has been shown that the genetic origin of birds affected utilization of carbohydrate and fat by increasing carbohydrate oxidation and reducing liponeogenesis, hence reducing the heat increment in a strain with better performance. The aim of the present preliminary experiment was to quantify oxidation of carbohydrates and fat in newly hatched chickens from fast and slow growing lines in order to elucidate whether breeding affected oxidative patterns.

\section{MATERIAL AND METHODS}

The experiment was conducted on 12 newly hatched White Plymouth Rock chickens from the fast growing line, Ross 308 (A), and 12 from the slow growing line, Labresse (B). The chickens were taken from a previous experiment with cmbryos in which gas exchange was measured. The two lines of chickens were kept separately with equipment for heating, feeding and drinking. The temperature was gradually decreased from $32^{\circ} \mathrm{C}$ on the $1^{\text {st }}$ day after hatching to $20^{\circ} \mathrm{C}$ on the $13^{\text {th }}$ day. The relative humidity was kept between $60-70 \%$ and artificial lighting for $24 \mathrm{~h}$. The chickens were fed ad libitum with a commercial feed compound containing $180 \mathrm{~g}$ crude protein, 610 $\mathrm{g}$ carbohydrate. $40 \mathrm{~g}$ crude fat and $16.2 \mathrm{MJ}$ gross energy per $\mathrm{kg}$ feed.

There was a three-day difference in age between the chickens due to the difference in age of the embryos, allowing the gas exchange measurements to be made exactly $1-4-7-10$ and 13 days after hatching.

Gas exchange was measured individually in an open-air-circuit respiration unit with 4 small chambers with a volume of $2000 \mathrm{~cm}^{3}$ (Micro-Max, Columbus Instrument, Ohio, USA). As feeding and watering were not possible in the chambers, the measurements were restricted to $3 \mathrm{~h}$. The climate in the chambers was identical with that in the cages.

The data from $\mathrm{O}_{2}$ consumption and $\mathrm{CO}_{2}$ production were used to calculate oxidation of carbohydrate (OXCHO) and fat (OXF) in accordance with the following equations (Chwalibog, 2002):

$$
\begin{aligned}
\mathrm{OXCHO}, \mathrm{kJ} & =\left(-2.968 \times \mathrm{O}_{2}, 1+4.174 \times \mathrm{CO}_{2}, 1-2.446 \times \mathrm{UN}, \mathrm{g}\right) \times 17.58 \\
\mathrm{OXF}, \mathrm{kJ} & =\left(1.719 \times \mathrm{O}_{2}, \mathrm{l}-1.719 \times \mathrm{CO}_{2}, \mathrm{l}-1.963 \times \mathrm{UN}, \mathrm{g}\right) \times 39.76
\end{aligned}
$$

Urinary nitrogen (UN) was not measured and was not taken into account in this experiment.

\section{RESULTS}

The variation between chickens in their gas exchange was high, due to the short duration of measurements and because the chickens were in different stages 
of digestion. However, it was possible, despite the high variation, to compare the general pattern of $\mathrm{OXCHO}$ and $\mathrm{OXF}$ in lines $\mathrm{A}$ and $\mathrm{B}$.

The heat from OXCHO (Figure 1) showed a steady increment from $1-14 \mathrm{~kJ} / \mathrm{h}$ in line $\mathrm{A}$ from the $1^{\text {st }}$ to the $13^{\text {th }}$ day after hatching, while line $\mathrm{B}$ was stabilized around 3 $\mathrm{kJ} / \mathrm{h}$ from the $7^{\text {th }}$ day. The heat from OXF (Figure 1) showed a different pattern with a steady value around $1 \mathrm{~kJ} / \mathrm{h}$ for line $\mathrm{A}$, while line B increased from 1 to $6 \mathrm{~kJ} / \mathrm{h}$.
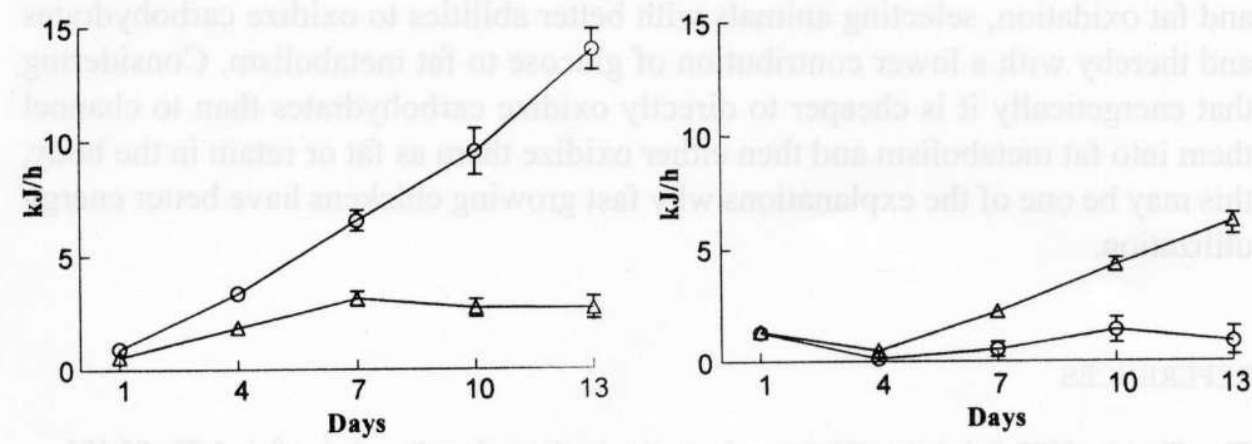

Figure 1. Oxidation of carbohydrate (left) and fat (right) in line Ao and $\mathrm{B} \Delta$. Mean and SEM

Heat production calculated as the sum of heat from OXCHO and OXF increased from 2 to $15 \mathrm{~kJ} / \mathrm{h}$ in line A and only from 2 to $9 \mathrm{~kJ} / \mathrm{h}$ in line B. Feeding was not possible in the respiration chambers, but from observations in the cages it was obvious that line A showed much greater eagerness in eating than line B, leading to higher body gains (227 vs $127 \mathrm{~g}$ ) and a final liveweight (327 vs $166 \mathrm{~g}$ ), thereby causing higher heat production.
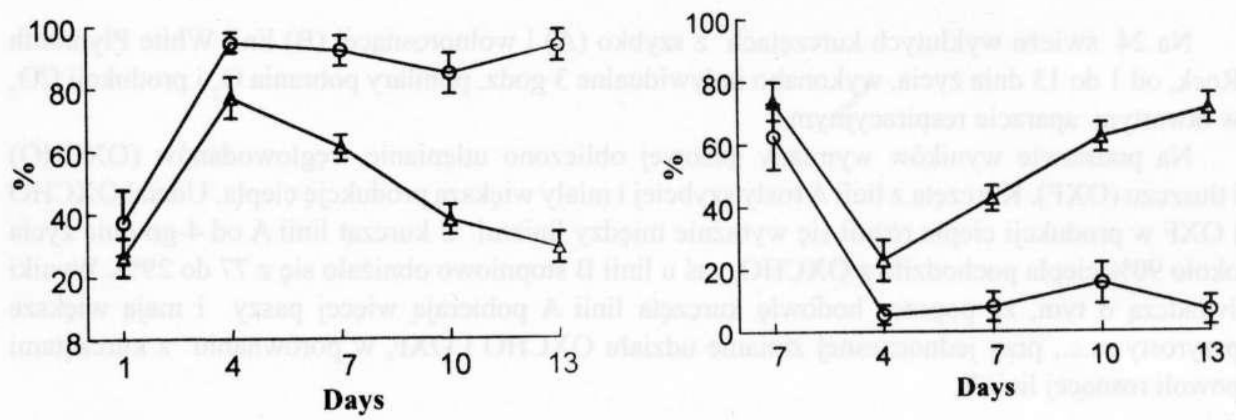

Figure 2. Oxidation of carbohydrate (left) and fat (right) in relation to heat production in line Ao and $\mathrm{B} \Delta$. Mean and SEM

All chickens from both lines covered their energy requirement on the first day after hatching with about $70 \%$ OXF (Figure 2) caused by the oxidation of fat from 
the yolk sac, being replaced later by increasing oxidation of dietary carbohydrate (Sklan, 2003). However, it is remarkable that this experiment showed pronounced differences between lines $\Lambda$ and $\mathrm{B}$ regarding the contribution of $\mathrm{OXCHO}$ and OXF to HE. From the $4^{\text {th }}$ day of age about $90 \%$ of the heat was constantly covered by $\mathrm{OXCHO}$ in line A, while it decreased gradually from 77 to $29 \%$ in line $\mathrm{B}$. The results indicate that breeding in line $A$, causing greater feed consumption and higher body gains, at the same time affected the proportion between carbohydrate and fat oxidation, selecting animals with better abilities to oxidize carbohydrates and thereby with a lower contribution of glucose to fat metabolism. Considering that energetically it is cheaper to directly oxidize carbohydrates than to channel them into fat metabolism and then either oxidize them as fat or retain in the body, this may be one of the explanations why fast growing chickens have better energy utilization.

\section{REFERENCES}

Chwalibog A., 2002. Substrate oxidation and retention in pigs and poultry. Anim. Sci. J. 73, 95-104

MacLeod M.G., Geraert P.A., 1988. Energy metabolism in genetically fat and lean birds and mammals. In: Leanness in Domestic Birds. Chapter 8. Butterworths

Sklan D., 2003. Fat and carbohydrate use in posthatch chicks. Poultry Sci. 82, 117-122

Sørensen P., Chwalibog A., Eggum B.O., 1983. Protein and energy metabolism in two lines of chickens selected for growth on high or low protein diets. Brit. Poultry Sci. 24, 237-250

\section{STRESZCZENIE}

\section{Utlenianie węglowodanów i tluszczu u świeżo wyklutych kurcząt}

Na 24 świezro wyklutych kurczętach z. szybko (A) i wolnorosnącej (B) linii White Plymonth Rock, od I do 13 dnia życia, wykonano indywidualne 3 godz, pomiary pobrania $\mathrm{O}_{2}$ i produkcji $\mathrm{CO}_{2}$ w otwartym aparacie respiracyjnym.

Na podstawie wyników wymiany gazowej obliczono utlenianie węglowodanów (OXCHO) i tłuszczu (OXF). Kurczęta z linii A rosły szybciej i miały większą produkcję ciepła. Udział OXCHO i OXF w produkcji ciepła różnił się wyraźnie między liniami. U kurcząt linii A od 4-go dnia życia około $90 \%$ ciepła pochodziło z OXCHO, zaś u linii B stopniowo obniżało sic̨ z 77 do $29 \%$. Wyniki świadczą o tym, że poprzez hodowlę kurczęta linii $\Lambda$ pobierają więcej paszy i mają większe przyrosty m.c., przy jednoczesnej zmianie udziału OXCHO i OXF, w porównaniu z kurczętami powoli rosnącej linii $\mathrm{B}$. 